\title{
EFEKTIFITAS AKUPRESUR TERHADAP PENURUNAN MUAL MUNTAH AKIBAT KEMOTERAPI DAN NYERI PADA PASIEN KANKER PAYUDARA
}

\author{
Endah Panca Lydia Fatma, Muladefi Choiriyah, Ridhoyanti Hidayah \\ Jurusan Keperawatan, Fakultas Kedokteran, Universitas Brawijaya \\ E-mail: endah.fk@ub.ac.id
}

\begin{abstract}
ABSTRAK
Kemoterapi merupakan salah satu terapi pada pasien kanker yang menimbulkan beberapa efek samping, salah satunya adalah mual muntah. Mual muntah masih dirasakan pasien walaupun sudah mendapatkan antiemetik. Mual muntah yang tidak dimanajemen dengan baik dapat mengakibatkan gangguan keseimbangan cairan dan elektrolit bahkan terganggunya siklus kemoterapi. Begitu pula dengan keluhan nyeri yang merupakan keluhan paling banyak pada penderita kanker yang dapat menurunkan kualitas hidupnya apabila tidak dimanagement dengan baik. Terapi akupresur merupakan salah satu terapi komplementer untuk mengurangi mual muntah akibat kemoterapi dan nyeri. Tujuan penelitian ini menganalisa efektifitas akupresur terhadap penurunan mual muntah dan nyeri akibat kemoterapi pada pasien kanker payudara. Penelitian quasi experiment ini melibatkan 16 responden. Akupresur diberikan menggunakan acupressure wristband selama hari ke 1-4 setelah kemoterapi. Mual-muntah dan nyeri diukur sebelum dan sesudah intervensi menggunakan kuesioner melalui metode telemonitoring. Selanjutnya, data dianalisis dengan menggunakan paired t-test untuk mual muntah dan Wilcoxon untuk nyeri. Hasil penelitian menunjukkan signifikansi perbedaan skor mual-muntah dan nyeri sebelum dan sesudah akupresure dengan nilai p-value 0.03 dan 0.026. Pemberian akupresur efektif menurunkan mualmuntah dan nyeri pada pasien kanker payudara dengan kemoterapi. Terapi akupresur secara signifikan dapat menurunkan mual muntah akibat kemoterapi dan nyeri pada pasien kanker payudara. Terapi akupresur direkomendasikan sebagai pertimbangan intervensi keperawatan dalam merawat pasien kanker payudara yang mengalami mual muntah akibat kemoterapi dan nyeri sehingga pasien dapat mengikuti siklus kemoterapi sesuai jadwal yang telah ditentukan dan meningkatkan kualitas hidupnya.
\end{abstract}

Kata kunci: Akupresur, Mual muntah, Nyeri, Kemoterapi, Kanker Payudara.

\section{ABSTRACT}

Chemotherapy is one of the therapies for cancer patients that cause some side effects, one of them is nausea and vomiting. Nausea and vomiting are still felt by patients even though they take antiemetics. Nausea dan vomiting can cause fluid and electrolyte imbalance. In other side, pain is the most clinical mannifestation in cancer patients that can reduce their quality of life if not properly managed. Acupressure therapy is one of the complementary therapies to reduce nausea and vomiting due to chemotherapy and pain. The aim of this study was to analysis the effectiveness of acupressure in decreasing nausea-vomiting and pain due to chemotherapy effect in breast cancer patients. This quasi experimental study was involved 16 respondents. Acupressure given by used an acupressure wristband for 1-4 days after chemotherapy. Nausea-vomiting and pain levels were measured pre-post acupressure through the questionnaire by telemonitoring method. Furthermore, the data were analyzed using paired t-test for nausea vomiting and Wilcoxon for pain. The results of this study there were significant differences nausea-vomiting and pain score before and after the acupressure intervention with a p-value 0.03 and 0.026. Acupressure therapy significantly reduce chemotherapy induce nausea and vomiting and pain in breast cancer patients. Acupressure therapy is recommended as a consideration for nursing interventions in treating breast cancer patients who experience nausea and vomiting due to chemotherapy and pain so that patients can follow the chemotherapy cycle according to a predetermined schedule and improve their quality of life.

Keywords: acupressure, nausea and vomiting, pain, chemotherapy, breast cancer. 


\section{PENDAHULUAN}

Kanker payudara adalah suatu penyakit neoplasma ganas yang berasal dari jaringan payudara, bisa berasal dari komponen kelenjarnya maupun komponen selain kelenjar (Smeltzer, Bare, Hinkle \& Cheever., 2010). Kanker payudara merupakan insiden kanker kedua terbanyak di dunia dan merupakan jenis kanker terbanyak yang dijumpai pada wanita. Untuk menekan pertumbuhan sel-sel ganas tersebut penderita kanker payudara memerlukan suatu terapi baik itu terapi secara lokal maupun sistemik seperti kemoterapi. Dimana obat kemoterapi tidak dapat membedakan sel kanker yang tumbuh cepat dengan sel normal yang tumbuh cepat, sehingga sel normal yang tumbuh cepat juga ikut dihancurkan misalnya sel di saluran pencernaan sehingga sering muncul keluhan mual muntah (Reed \& Audisio, 2010; Smeltzer Bare, Hinkle \& Cheever., 2010).

Secara farmakologis, antiemetik yang sering digunakan pada pasien kanker payudara yang menjalani kemoterapi adalah jenis 5HT3 reseptor antagonis dan dexamethasone untuk mual muntah akut, dan metoclopramide, dexamethasone untuk mual muntah lambat (Karch, 2011). Meskipun temuan agen antiemetik tersebut telah berkembang pesat, namun muntah yang tidak terkontrol dan pengendalian mual yang tidak adekuat masih menjadi masalah utama pada pasien kanker yang menjalani kemoterapi (Hesketh, 2008). Selain itu, beberapa efek samping seperti sakit kepala, myalgia, hipotensi, retensi urin dan konstipasi dapat menimbulkan rasa tidak nyaman pada pasien (Karch, 2011). Oleh karena itu, dibutuhkan suatu terapi komplementer untuk mengurangi efek mual muntah akibat kemoterapi.

Berdasarkan telaah literature terdapat beberapa terapi non farmakologi yang disarankan sebagai terapi pendamping terapi medis, diantaranya yaitu akupuntur, akupresur, progressive muscular relaxation, imagery guidance dan terapi musik (Pieszak, 2011). Terapi non farmakologi sangat bermanfaat apabila dikombinasikan dengan antiemetik. Penelitian sebelumnya yang dilakukan oleh Fatma (2015) tentang pengaruh penggunaan acupressure wristband untuk mengurangi mual muntah akibat kemoterapi pada pasien kanker payudara. Hasil penelitian menunjukkan bahwa akupresur dengan menggunakan acupressure wristband dapat menurunkan mual muntah akibat kemoterapi.

Selain mual muntah, penderita kanker juga mengalami nyeri akibat pendesakan masa dari tumor yang mengenai syaraf. Nyeri pada kanker tidak saja disebabkan oleh mediator kimia dari sel namun juga oleh pengobatan antikanker itu sendiri. Penelitian lain yang dilakukan oleh Sima (2009) tentang akupuntur menunjukkan bahwa akupuntur dapat menurunkan nyeri pada pasien dengan kanker payudara. Dimana pelepasan mediator-mediator vaskuler dan neuroaktif akibat akupunktur memungkinkan mengurangi beberapa keluhan akibat kanker seperti nyeri, mual dan muntah 
Endah P. L.F., Muladefi C, Ridhoyanti H, Efektifitas Akupresur.....

pasca kemoterapi, xerostomia, hotflash, kelelahan, kecemasan, depresi dan insomnia (Tsai, 2011). Sampai saat ini pada populasi di Indonesia belum ada penelitian tentang efektifitas terapi akupresur dalam menurunkan mual muntah akibat kemoterapi dan nyeri pada pasien kanker payudara. Tujuan penelitian ini adalah menganalisa efektifitas akupresur terhadap penurunan mual muntah akibat kemoterapi dan nyeri pada pasien kanker payudara sebelum dan sesudah terapi.

\section{METODE}

Penelitian ini dilakukan di RST dr. Soepraoen Malang pada tahun 2017. Desain yang digunakan adalah quasi experiment melalui pendekatan one group pre-post test design study. Sampel penelitian ini memiliki kriteria inklusi sebagai berikut: Pasien dengan kanker payudara yang berusia $>18$ tahun, siklus kemoterapi ke 2-5, mendapat regimen terapi apapun, mengalami mual muntah pada siklus sebelumnya, bersedia menggunakan alat acupressure wristband hari ke 1-4 setelah kemoterapi dengan minimal penggunaan 12 jam sehari. Kriteria eksklusi dalam penelitian ini adalah: kontraindikasi akupresur; kulit yang terluka, bengkak, tulang retak, kulit yang terbakar. Penilaian mual-muntah menggunakan instrument Rhodes Index Nausea, Vomiting and Retching (INVR) sedangkan nyeri menggunakan Visual Analogue Scales (VAS).

Pengumpulan data dalam penelitian ini dilakukan setelah pasien memenuhi kriteria inklusi dan eksklusi serta menandatangani informed consent setelah diberikan penjelasan. Sebelum dilakukan intervensi peneliti melakukan penilaian mual muntah dan nyeri pada semua responden sebagai data pretestyang dilakukan pada 24 jam setelah pasien menjalani kemoterapi. Wawancara tersebut dilakukan melalui metode telemonitoring. Intervensi yang diberikan adalah akupresur dengan menggunakan alat berupa acupressure wristband pada titik akupuntur yaitu titik P6 (pericardium atau neiguan 6) pada kedua lengan responden dan diberikan penekanan pada titik L14 di punggung tangan yang diajarkan oleh peneliti. Intervensi diberikan hari ke 1-4 setelah kemoterapi. Untuk data posttest, data diambil pada akhir intervensi pada hari ke-4 dengan menggunakan metode yang sama dengan saat pretest. Dalam penelitian ini semua responden tetap diberikan terapi standar dengan antiemetik untuk mengurangi mual muntah sesuai dengan indikasi untuk mengurangi bias. Penelitian ini telah dinyatakan laik etik dari Komite Etik Penelitian Kesehatan Fakultas Kedokteran Universitas Brawijaya.

Analisa bivariat dilakukan untuk mengetahui perbedaan rerata skor mual-muntah dan nyeri pada sebelum dan sesudah dilakukan intervensi. Uji normalitas dilakukan terlebih dahulu dengan menggunakan uji Shapiro-wilk. Analisis yang digunakan adalah Uji paired t-test dan Wilcoxon. Paired t-test digunakan untuk menguji skor Mual-muntah karena data berdistribusi normal ( $\mathrm{p}$ value $=0.080$ ), sedangkan uji Wilcoxon digunakan untuk menguji skor nyeri karena data tersebut tidak 
berdistribusi normal ( $\mathrm{p}$ value $=0.047)$.

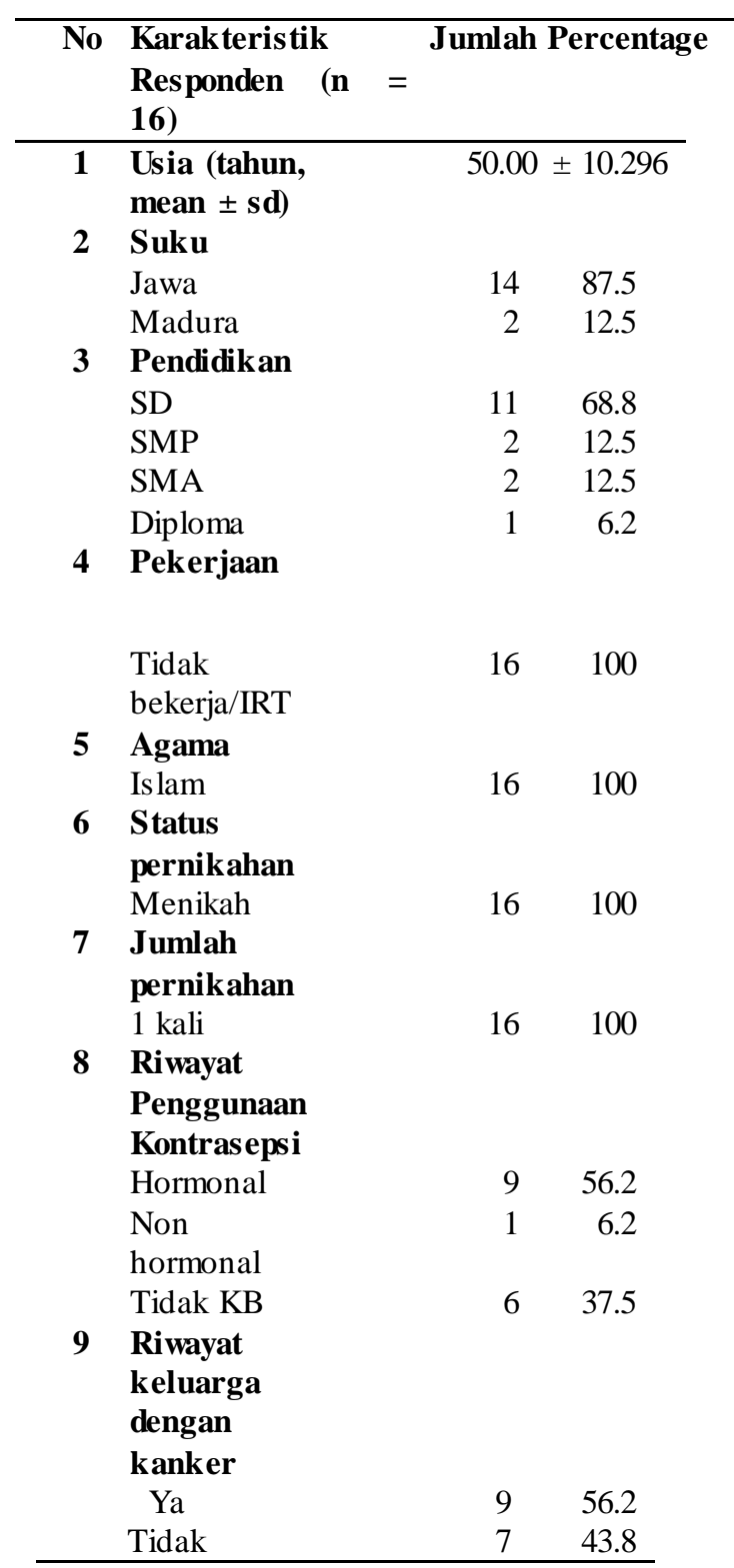

\section{HASIL DAN PEMBAHASAN}

Enam belas orang responden perempuan terlibat dalam penelitian ini hingga akhir pengambilan data. Karakteristik responden pada penelitian ini tertera dalam tabel 1. Kondisi responden terkait kanker payudara seperti status operasi, diagnosa medis, obat kemoterapi, jumlah siklus kemoterapi, dan efek sampingnya tertera pada table 2 .
Tabel 1. Karakteristik Responden Berdasarkan tabel 1 tersebut karakteristik responden dalam penelitian ini sebagian besar pernah menggunakan Kontrasepsi hormonal (56.2\%) dan memiliki riwayat keluarga dengan kanker $(56.2 \%)$

\begin{tabular}{|c|c|c|c|}
\hline No & $\begin{array}{c}\text { Kondisi } \\
\text { Responden } \\
\text { terkait Ca } \\
\text { Mamae }(\mathrm{n}=16)\end{array}$ & $\mathbf{J m I}$ & Percentage \\
\hline \multirow[t]{2}{*}{1} & $\begin{array}{l}\text { Status Operasi } \\
\text { Kanker Payudara }\end{array}$ & & \\
\hline & $\begin{array}{l}\text { Pre-operasi } \\
\text { Post-operasi }\end{array}$ & 9 & $\begin{array}{l}56.2 \\
43.8\end{array}$ \\
\hline \multirow[t]{8}{*}{2} & $\begin{array}{l}\text { Diagnosa Kanker } \\
\text { Pavudara }\end{array}$ & & \\
\hline & $\begin{array}{l}\text { Ca Mamae D } \\
\text { Ca Mamae D }\end{array}$ & 2 & $\begin{array}{l}12.5 \\
0.2\end{array}$ \\
\hline & $\begin{array}{l}\text { T2N1Mo } \\
\text { Ca Mamae S }\end{array}$ & 3 & 18.8 \\
\hline & Ca Mamae S & 1 & 0.2 \\
\hline & Ca Mamae $\mathrm{s}$ & 1 & 0.2 \\
\hline & $\begin{array}{l}\text { T2NOMO } \\
\text { T2NO }\end{array}$ & 1 & 0.2 \\
\hline & T3PNOMO & 1 & $\begin{array}{l}12.5 \\
500.2\end{array}$ \\
\hline & $\begin{array}{l}\text { T4bN1Mo } \\
\text { T4cN1Mx }\end{array}$ & & \\
\hline \multirow[t]{9}{*}{3} & Obat Kemoterap & & \\
\hline & $\begin{array}{l}\text { yang digunakan } \\
\text { Doxorubicin } 70, \\
\text { curacil } 750, \\
\text { endoxan }\end{array}$ & 2 & 12.5 \\
\hline & $\begin{array}{l}\text { endoxan } \\
\text { Endoxan } 1000 \text {, }\end{array}$ & 2 & 12.5 \\
\hline & $\begin{array}{l}\text { paxus } 230 \\
\text { Paxus } 230\end{array}$ & 3 & 18.8 \\
\hline & $\begin{array}{l}\text { endoxan } 800 \\
\text { Sindaxel } 230\end{array}$ & 1 & 6.2 \\
\hline & $\begin{array}{l}\text { endoxan } 800 \\
\text { Cyclovid } 800 \text {, }\end{array}$ & 3 & 18.8 \\
\hline & $\begin{array}{l}\text { sindaxel } 230 \\
\text { Curacyl } 750 \\
\text { cyclovid 800, }\end{array}$ & 2 & 12.5 \\
\hline & $\begin{array}{l}\text { doxorubicin } \\
\text { Gemcytabin 230, }\end{array}$ & 1 & 6.2 \\
\hline & $\begin{array}{l}\text { Sindaxel } 230 \\
\text { cyclo } 800\end{array}$ & 2 & 12.5 \\
\hline \multirow[t]{4}{*}{4} & $\begin{array}{l}\text { Siklus } \\
\text { kemoterapi saat } \\
\text { ini }\end{array}$ & & \\
\hline & $2 \mathrm{kali}$ & 4 & 25 \\
\hline & 3 kali & 8 & 50 \\
\hline & $5 \mathrm{kali}$ & 4 & 25 \\
\hline \multirow[t]{3}{*}{5} & $\begin{array}{l}\text { Riwayat Nyeri } \\
\text { setelah } \\
\text { kemoterapi }\end{array}$ & & \\
\hline & Ya & 13 & 81.2 \\
\hline & Tidak & 3 & 18.8 \\
\hline \multirow[t]{4}{*}{6} & $\begin{array}{l}\text { Pengalaman } \\
\text { mual-muntah } \\
\text { setelah } \\
\text { kemoterapi }\end{array}$ & & \\
\hline & $\mathrm{Ya}$ & & 68.8 \\
\hline & & 11 & \\
\hline & Tidak & 5 & 31.2 \\
\hline
\end{tabular}


Endah P. L.F., Muladefi C, Ridhoyanti H, Efektifitas Akupresur.....

Tabel 2. Kondisi Responden Terkait Kanker Payudara

Berdasarkan tabel 2 Rata-rata diagnosa kanker payudararesponden pada stadium 2 hingga 4. Obat-obatan yang digunakan golongan high emetogenic (pemicu mual lebih tinggi) seperti sindaxel dan endoxan, dan paxus pada 13 responden $(81.25 \%)$.

Hasil Analisa data pada variable skor mual-muntah dan skor nyeri tertera pada tabel 3 . Pada variabel mual muntah menggunakan uji paired t-test karena data berdistribusi normal sedangkan pada variable nyeri menggunakan uji Wilcoxon karena data tidak berdistribusi normal. Tabel 3 Analisa Perbedaan Mual-Muntah dan Nyeri sebelum dan sesudah intervensi

\begin{tabular}{cccc}
\hline \multicolumn{2}{c}{ Rerata Skor Mual } & \multicolumn{2}{c}{ Rerata Skor } \\
$\begin{array}{ccc}\text { Muntah } \\
\text { Pre }\end{array}$ & $\begin{array}{c}\text { Post } \\
\text { Posd) }\end{array}$ & \multicolumn{2}{c}{ Nyeri $($ mean \pm sd) } \\
Pre & Post \\
\hline $14.34 \pm$ & $7.75 \pm$ & $6.61 \pm$ & $5.31 \pm$ \\
3.24 & 2.54 & 1.36 & 0.60 \\
p-value & $=\mathbf{0 . 0 3 *}$ & p-value & $=\mathbf{0 . 0 2 6} *$ \\
\hline
\end{tabular}

Berdasarkan tabel tersebut terdapat penurunan rata-rata skor mual-muntah dan nyeri, serta terdapat signifikansi masing-masing dengan nilai $\mathrm{p}$-value 0.03 dan 0.026 .

Penelitian ini menunjukkan bahwa terapi akupresur dengan menggunakan acupressure wristband yang dikombinasikan dengan antiemetik memberikan pengaruh terhadap mual muntah akibat kemoterapi pada pasien kanker payudara. Hal ini ditunjukkan dalam tabel 3 dengan adanya perbedaan rerata mual muntah $(\mathrm{p}=0.03)$ sebelum dan sesudah diberikan intervensi terapi akupresur dengan acupressur wristband. Kondisi yang dilaporkan responden dalam penelitian ini setelah menjalani kemoterapi di rumah sakit, sebagian besar mengatakan bahwa mengalami episode mual muntah yang memberat pada hari kedua dan ketiga setelah kemoterapi. Hal ini sesuai dengan penelitian Rusthoven, Osoba, Butts, Yelle, Dindlay dan Grenville (2008) bahwa pada 52\% pasien mengalami mual muntah dengan tingkatan severe atau parah.

Pada penelitian ini, selain mendapatkan terapi akupresur dengan pemasangan acupressure wristband responden juga mendapatkan terapi standar (antiemetik) berupa ondansentron, ranitidine dan dexamethasone yang diberikan sebelum kemoterapi dan metoclopramide sesudah kemoterapi. Adanya kombinasi antara terapi farmakologi dan pemasangan alat berupa acupressure wristband membuat penurunan mual muntah menjadi lebih signifikan.

Penelitian ini sejalan dengan penelitian yang dilakukan oleh Said (2009), yang melakukan penelitian di Palestina untuk membandingkan perbedaan mual muntah pada 42 pasien kanker servix yang menjalani kemoterapi cisplatin dengan menggunakan metode post test control group design. Hasil penelitian menunjukkan bahwa kelompok yang mendapatkan akupresur dengan menggunakan wristband mengalami penurunan pada mual muntah bila dibandingkan dengan kelompok yang mendapatkan placebo akupresur dan terapi standar. Eunice (2012) juga melakukan penelitian serupa dengan menggunakan wristband dan konseling pada kelompok 
Endah P. L.F., Muladefi C, Ridhoyanti H, Efektifitas Akupresur.....

intervensi untuk mengurangi mual muntah akibat kemoterapi pada pasien kanker payudara. Hasil penelitian menunjukkan bahwa akupresur pada titik P6 disertai konseling tentang managemen mual muntah dapat menurunkan mual muntah.

Mual dan muntah disebabkan oleh agen kemoterapi (Chemotherapy Induced Nausea and Vomiting/ CINV)yang menstimulasi sel enterochromafin dalam saluran pencernaan untuk melepaskan serotonin, yang mengaktivasi reseptor serotonin (Wood et al., 2007). Aktivasi reseptor mengaktifkan jalur aferen vagal, yang mengaktivasi pusat muntah dan menyebabkan respon emetik. Potensi emetik dari agen kemoterapi merupakan stimulus utama terhadap mual muntah yang disebabkan oleh agen kemoterapi (Aapro et al., 2013). Akupresur sebagai terapi komplementer memberikan stimulus pada titik Pericardium 6 di lengan dengan menstimulasi peningkatan jumlah beta endorphin di hipotalamus. Dimana peningkatan yang maksimal terjadi setelah 25 menit dilakukan akupresur (Samad, Afshan \& Kamal, 2003). Pada penelitian ini, penggunaan acupressure wristband dengan menekan pada titik P6 diasumsikan memiliki efek terapi yang sama dengan pemberian akupresur secara manual melalui pijatan atau penekanan. Dengan menekan titik P6 akan menstimulasi pegeluaran beta endorphin.

Peningkatan konsentrasi beta endorphin akan mengaktifkan saraf parasimpatis. Saraf parasimpatis akan menurunkan kerja syaraf vagal abdominal untuk menurunkan aktifitas lambung baik itu pada peristaltik maupun produksi asam lambung. Selain itu perangsangan di pericardium melalui serabut syaraf yang membawa aliran neurotransmiter ke otak juga menghambat rangsang pada syaraf aferen untuk memberikan sinyal pada batang otak bagian belakang. Selanjutnya, beberapa reseptor penyebab mual muntah menjadi terhambat (5hydroxytriptamine3 (5HT3), neurokinin-1, dan cholecystokinin-1). Beta endorphin yang diaktivasi melalui akupresur juga merupakan salah satu antiemetik alami yang mampu menurunkan stimulus mual muntah di CTZ atau pusat muntah sehingga dapat menurunkan mual muntah (Eunice, 2012).

Menurut terapi pengobatan China, mual muntah terjadi akibat tersumbatnya atau terjadi ketidakseimbangan energi vital di lambung akibat berbagai hal. Akupresur pada titik P6 diyakini dapat memperbaiki energi vital di lambung sehingga lambung dapat bekerja dengan normal. Energi yang berada dalam kondisi seimbang akan dapat menjalankan fungsinya dalam memberikan nutrisi ke jaringan, mengaktivasi fungsi organ-organ dan keseimbangan fungsi tubuh (Dibble, et al, 2007; Eunice, 2012). Penyakit terjadi jika ada kondisi ketidakharmonisan energi atau $q i$ dalam tubuh, baik berupa terhambatnya aliran $q i$ maupun kekurangan qi. Mual muntah terjadi akibat adanya aliran $q i$ yang tidak berada pada alirannya sehingga menyebabkan ketidakseimbangan energi di lambung dan limpa. Tindakan yang dilakukan adalah dengan memanipulasi titik-titik yang berada di 
Endah P. L.F., Muladefi C, Ridhoyanti H, Efektifitas Akupresur.....

sepanjang meridian atau serabut saraf yang mengenai lambung dan limpa, sehingga energi yang tidak harmonis tersebut kembali ke dalam kondisi yang seimbang (Sukanta, 2008).

$$
\text { Grunberg \& Ireland }
$$
mengungkapkan bahwa mual muntah akibat kemoterapi dipengaruhi oleh siklus kemoterapi. Hal ini secara emosional membuat pasien merasa lebih baik karena merasa akan mengakhiri pengobataannya. Proses adaptasi pasien terhadap gejala-gejala yang dialami selama menjalani kemoterapi juga mempengaruhi terhadap kejadian mual muntah. Baradero (2008) mengungkapkan bahwa ketika seseorang yang menderita kanker payudara dan sering menjalani kemoterapi maka koping terhadap gejala-gejala yang muncul akan lebih baik, karena pasien tersebut sudah terbiasa dan sudah mengetahui cara mengatasi gejala-gejala tersebut. Syarif (2014) juga melakukan penelitian tentang kualitas hidup pasien kanker payudara pada setiap siklus kemoterapi. Hasil penelitian menunjukkan bahwa kualitas hidup pasien pada siklus kelima 80\% menyatakan baik, yang ditunjukkan dengan status fungsional yang berfungsi baik seperti fungsi fisik, peran, emosional, sosial dan kognitif.

Insiden mual muntah akibat kemoterapi sebagian besar dialami oleh responden pada hari kedua sampai keempat. Namun tidak sedikit juga responden yang menyatakan bahwa mual muntah masih dialami sampai hari ke 10 bahkan dua minggu setelah kemoterapi. Mual muntah yang masih dialami hingga 10 hari setelah kemoterapi kemungkinan disebabkan oleh faktor usia, tingkat pendidikan maupun gender. Selain itu, kejadian mual muntah juga pengaruhi oleh jenis obat kemoterapi yang berpotensi emetik dan riwayat mual muntah pada siklus kemoterapi sebelumnya.

Responden pada penelitian ini $68.8 \%$ memiliki riwayat mual muntah pada siklus kemo sebelumnya terutama pada responden yang menjalani kemoterapi lebih dari 1 kali. Molassiotis et al (2007), menyatakan bahwa pengalaman mual muntah akibat kemoterapi sebelumnya memiliki resiko terjadinya mual muntah sehingga penanganan awal perawatan mual muntah dapat menyebabkan pengelolaan mual muntah akibat kemoterapi lebih adekuat. Penelitian lain menunjukkan hasil bahwa pengalaman mual muntah pasien mempengaruhi terhadap pengambilan keputusan tentang perawatan mual muntah pada siklus yang akan dijalani selanjutnya.

Pada penelitian ini juga mengajarkan pasien dengan memberikan stimulus pada titik LI4 sebagai titik accupoint untuk mereduksi nyeri. Pada pasien kanker, nyeri yang dialami merupakan keluhan baling banyak yang dirasakan pasien. Hal ini terjadi karena proses penyakit itu sendiri maupun akibat terapi yang dijalani pasien, atau akibat co morbiditas yang dialami selama menderita kanker. Tata lakasana nyeri dapat dilakukan dengan pemberian analgesik dan terapi non farmakologi. Mekanisme neurofisiologi akupresur pada titik LI4 di tangan berperan sebagai analgesik alami yang distumulus melalui beberapa mekanisme 
Endah P. L.F., Muladefi C, Ridhoyanti H, Efektifitas Akupresur.....

yaitu inhibisi pelepasan serotonin, substance $\mathrm{P}$, dan opiate endogen yang berperan pada beberapa pathway di sistem saraf pusat. Inhibisi reseptor serotonin yang bekerja di system saraf pusat inilah yang berperan sebagai penurun nyeri.

Sebuah studi mengungkapakan bahwa peran peptide opioid endogen pada sistem saraf pusat dapat ditimbulkan oleh efek analgesik dari elektro akupunktur. Beberapa jenis neuropeptide dapat dilepaskan akibat elektro akupunktur (EA) tergantung dari frekuensi yang digunakan. Berdasar ilmu neurobiologi, mekanisme akupunktur dan akupresur dalam pengobatan penyakit dimediasi oleh sistem saraf. Stimulasi penusukan pada akupoint menginisiasi adanya sinyal akupunktur yang berjalan melalui serat saraf dan menginervasi jaringan yang lebih dalam dekat akupoint. Sinyal akupunktur ditransmisikan menuju sistem saraf pusat, kemudian mengaktifkan dan mengintegrasikan dengan neuron yang beradapada area korteks, sistemlimbik, batangotak, spinal cord, kemudian turun dan meregulasi sistem lain (Zhu, 2010). Penusukan jarum akupunktur menyebabkan adanya impuls yang bergerak dari satu cabang saraf ke cabang lain yang berdekatan dengan jaringan non saraf, pembuluh darah, kelenjar keringat dan sel mast yang disebut reflex akson. Reflek akson tersebut menyebabkan vasodilatasi dan pelepasan mediator-mediator vascular dan neuroaktif dari sel-selimun.

$\begin{array}{cccc} & \text { Adanya } & \text { pelepasan mediator- } \\ \text { mediator vaskuler dan neuroaktif akibat }\end{array}$

akupunktur memungkinkan akupunktur mampu mengurangi beberapa keluhan akibat kanker seperti nyeri, mual dan muntah pasca kemoterapi, xerostomia, hotflash, kelelahan, kecemasan, depresi dan insomnia (Johnstone et al., 2002; O'Regan and Filshie, 2010). Pasien kanker dengan keluhan hotflash akibat ketidakseimbangan hormon juga dapat mengalami perbaikan setelah akupunktur. Akupunktur merupakan metode pengobatan yang aman dengan efek samping yang sangat minimal.

Dari pembahasan di atas menunjukkan bahwa penggunaan acupressure wristband yang dikombinasikan dengan antiemetik memberikan pengaruh lebih baik terhadap penurunan mual muntah responden dibandingkan dengan responden yang hanya menerima terapi standar antiemetik saja. Peneliti meyakini bahwa penurunan mual muntah dalam penelitian ini adalah dari pengaruh acupressure wristband yang diberikan. Dimana responden dalam penelitian ini juga memiliki skor mual muntah sebelum dan setelah penelitian. Adapun karakteristik yang dicurigai mempengaruhi mual muntah sudah dilakukan pengontrolan untuk meminimalkan bias.

\section{KESIMPULAN}

Pemberian akupresur terhadap penurunan mual muntah akibat kemoterapi dan nyeri secara signifikan efektif dalam menurunkan mual muntah dan nyeri akibat 
kemoterapi pada pasien kanker payudara. Pemberian terapi akupresur direkomendasikan sebagai intervensi keperawatan dalam merawat pasien kanker payudara yang mengalami mual muntah dan nyeri sehingga pasien dapat mengikuti siklus kemoterapi sesuai jadwal yang telah ditentukan dan meningkatkan kualitas hidup.

\section{DAFTAR RUJUKAN}

Aapro M, Karin J \& Petra F. (2013). Pocket books for cancer supportive care: prevention of nausea and vomiting in cancer patients. London: Springer Healthcare.

Baradero, M., Dayrit, M. W, dan Siswadi, Y. (2008). Seri Asuhan Keperawatan pada Klien Kanker. Jakarta: EGC.

Fatma E. (2015). Pengaruh penggunaan terapi kombinasi acupressure wristband dan antiemetik yang dikombinasikan dengan obat antiemetik terhadap mual muntah akibat kemoterapi pada pasien kanker payudara di RSP Unpad - RSUP Dr. Hasan Sadikin Bandung. Tesis.

Dibble, S.L., Luce, J, Cooper, B.A \& Israel, J. (2007). Accupressure for chemotherapy induced nausea and vomiting a randomized clinical trial. Oncology Nursing Forum, 34 (4), 813-820.

Eunice, E. (2012). The effects of p6 acupressure and nurse provided conseling on chemotherapy induced nausea and vomiting in patients with breast cancer. Oncology Nursing Forum. Vol. 39 No.1.

Grunberg, S. M. (2004). Chemotherapy induced nausea vomiting: prevention, detection and treatment-how are we doing. The Journal of Supportive Oncology, 2 (1), 1-12.

Hesketh, P.J. (2008). Chemotherapy induced nausea and vomiting.The New England Journal of Medicine, 358 (23), 24822494.

Johnstone, Astrid A. Ruefli., Scott. (2012). Cell volume 108 , issue $2,153-164$.
Karch, A., RN, MS. (2011). Focus on nursing pharmacology. Philadelphia: Lippincott Williams \& Wilkins.

O'Regan. (2010). Age / Race Diferences in HER2 testing and in incidence rates for breast cancer triple subtypes. Cancer Journal Clinic. Vol 11 (2).

Pieszak, S. (2011). Cancer based interventions for chemotherapy induced nausea and vomiting. The Oncology Nursing Society. Vol.6. No. 10.

Reed M., \& Audisio R. (2010). Management of Breast Cancer in Older Women. New York: Springer Publishing Company.

Rhodes, V. A., \& Mc Daniel, R, W. (2004). Nausea, vomiting \& retching: complex problem in palliative care. Cancer Journal Clinic. 51(4), 232-248.

Said, Z. M. O. (2009). Acupressure for chemotherapy induced nausea and vomiting in cancer patients: a multicentre randomized double blind, placebo-controlled clnical trial. An Najah National University Faculty of Graduate Studies.

Samad, K., Afshan, G, \& Kamal, R. (2003). Effect of acupressure on postoperative nausea and vomiting in laparascopic cholecystectomy. Journal Med Assoc, 53 (2); 68-72.

Sima, L., \& Wang, X. (2009). Therapeutic effect of acupuncture on cisplatin induced nausea and vomiting. Chinese acupuncture and moxibustion. 29: 3-6.

Smeltzer, S. C., Bare, B. G., Hinkle, J. L., \& Cheever, K. H. (2010). Brunner \& Suddarth's textbook of medical surgical nursing $\quad\left(12^{\text {th }} \quad\right.$ ed $) . \quad$ Philadelphia: Lippintcott Williams \& Wilkins.

Synder, M. \& Lindquis, R. (2002). Complementary as alternative therapies in nursing. $4^{\text {th }}$ ed. New York: Springer.

Tsai Y. 2011. Acupuncture nerve stimulation and pain. The Daytona Beach News Journal 